\title{
Pembelajaran Induktif Pada Kemampuan Penalaran Matematis dan Self-Regulated Learning Siswa
}

\author{
Nopia Wanti'), Juariah ${ }^{1)}$, Ehda Farlina ${ }^{1 *}$, Hamdan Sugilar ${ }^{1)}$ Rahayu \\ Kariadinata $^{1)}$ \\ ${ }^{1}$ Prodi Pendidikan Matematika, UIN Sunan Gunung Djati Bandung, \\ J1. A.H. Nasution No. 105, Bandung 40614, Indonesia \\ ${ }^{1 *}$ E-mail: ehda.farlina@uinsgd.ac.id
}

Dikirim: Februari 2017; Diterima: Mei 2017; Dipublikasikan: Juni 2017

\begin{abstract}
Abstrak. Penelitian ini dilatarbelakangi oleh kemampuan penalaran matematis siswa di SMP Triyasa yang masih perlu dikembangkan dan ditingkatkan. Penelitian ini bertujuan untuk mengetahui: (a) gambaran proses pembelajaran matematika dengan menggunakan model pembelajaran induktif Taba dan pembelajaran induktif Sharan-Sharma, (b) kemampuan penalaran matematis, (c) self-regulated learning siswa yang menggunakan model pembelajaran induktif Taba dan pembelajaran induktif Sharan-Sharma. Penelitian ini dilaksanakan di kelas VII D, E, dan F SMP Triyasa Bandung yang menggunakan desain Penelitian KuasiEksperimen pada pokok bahasan Segiempat. Berdasarkan hasil penelitian diperoleh: (a) Gambaran proses pelaksanaan pembelajaran melalui gambaran aktivitas siswa dan aktivitas guru berdasarkan pengamatan observer secara umum terlaksana dengan cukup baik; (b) terdapat perbedaan pencapaian kemampuan penalaran matematis siswa antara yang menggunakan model pembelajaran induktif Taba, pembelajaran induktif Sharan-Sharma dengan pembelajaran konvensional. Perbedaan tersebut terdapat antara model pembelajaran induktif Taba dengan pembelajaran konvensional dan antara pembelajaran induktif Sharan-Sharma dengan pembelajaran konvensional. (c) self-regulated learning siswa yang menggunakan model induktif Taba dan induktif Sharan-Sharma menunjukkan sikap negatif.
\end{abstract}

Kata Kunci. Induktif Taba; Induktif Sharan-Sharma; Penalaran Matematis; Self-Regulated Learning

\section{Pendahuluan}

Matematika merupakan proses bernalar, pembentukan karakter dan pola pikir, pembentukan sikap objektif, jujur, sistematis, kritis dan kreatif serta sebagai ilmu penunjang dalam pengambilan suatu 
kesimpulan. Begitu banyak dan beragam profesi yang bisa dipilih sebagai bidang profesi berlandaskan pengetahuan dan keterampilan matematika. Misalnya: guru, ekonom, insinyur, ahli statistik, peneliti, dokter, apoteker, dan lain-lain. Hal ini sejalan dengan Tinggih (Tim MKPBM, 2003: 16) yang menyebutkan bahwa matematika merupakan pengetahuan yang diperoleh dengan bernalar. Berdasarkan pernyataan tersebut kemampuan penalaran matematis mempunyai peran yang sangat penting dalam matematika. National Council of Teachers of Mathematics (NCTM) (1989) merekomendasikan lima standar proses dalam pembelajaran matematika di sekolah, yaitu: pemecahan masalah (problem solving), komunikasi (communication), penalaran (reasoning), koneksi (connections) dan representasi.

Tahun 2007 TIMMS mengungkap hanya $17 \%$ (dari sampel yang diambil) anak indonesia yang dapat menjawab soal penalaran matematis (Armiati, 2011).Berdasarkan hasil tersebut diketahui bahwa kemampuan penalaran matematis siswa masih kurang, hal ini disebabkan karena siswa tidak terbiasa menyelesaikan permasalahan matematika non rutin berkaitan dengan penalaran. Hal itu sesuai pula dengan hasil penelitian Wahyudin (1999:192) yang menyatakan bahwa siswa kurang memiliki kemampuan nalar yang logis dalam menyelesaikan persoalan atau soal-soal matematika.

Lemahnya kemampuan penalaran matematis siswa tidak hanya dipengaruhi oleh beberapa faktor yang telah diutarakan sebelumnya, sesungguhnya yang lebih berpengaruh adalah siswa itu sendiri. Salah satu sikap yang sangat penting dalam mempelajari matematika adalah kemampuan siswa mengatur diri dalam belajar (Sumarni, 2014: 4). Menurut Pintrich (1990) kemandirian siswa (selfregulated learning) adalah cara belajar siswa aktif secara individu untuk mencapai tujuan akademik dengan cara pengontrolan prilaku, memotivasi diri sendiri dan menggunakan kognitifnya dalam belajar.Kemauan untuk mempelajari matematika yang dianggap sulit merupakan sikap yang akan berpengaruh negatif terhadap keberhasilan pembelajaran matematika.

Self-regulated learning penting dalam mempelajari matematika yang abstrak, berkaitan dengan banyaknya rumus-rumus yang digunakan yang bersifat absolut. Ketika siswa tidak hanya belajar matematika di sekolah, kemudian siswa belajar secara mandiri dengan mengerjakan latihan-latihan soal berulang-ulang di rumah siswa akan lebih mudah dalam 
mengonstruksi pengetahuannya sendiri. Dengan mengerjakan latihan soal penalaran berulang-ulang siswa akan lebih mudah dalam menghadapi tugas, lebih mudah mengingat rumus atau ketika siswa lupa rumus, siswa tidak akan terlalu sulit mengonstruksi rumus tersebut. Hal ini sesuai dengan yang diungkapkan Sumarmo (2013) bahwa self-regulated learningmerupakan proses perancangan dan pemantauan diri yang seksama terhadap proses kognitif dan afektif dalam menyelesaikan suatu tugas akademik.

Apabila siswa mempunyai self-regulated learning yang tinggi, siswa cenderung belajar lebih baik.Kurangnya aspek penalaran matematis siswa juga dikarenakan model pembelajaran matematika yang kurang memfasilitasi siswa untuk belajar secara aktif dan kurang mendorong siswa menggunakan penalaran, (Rosadi, 2013). Berdasarkan hasil penelitian tersebut guru sebaiknya mampu mengupayakan pembelajaran matematika yang dapat memfasilitasi pengembangan kemampuan berpikir, terutama berkaitan dengan kemampuan penalaran. Kemampuan penalaran dapat dikembangkan dengan menggunakan pembelajaran induktif.

Pembelajaran induktif menuntut siswa untuk aktif dalam proses pembelajaran, karena siswa dituntut untuk mengonstruksi pengetahuannya sendiri sehingga guru hanya berperan sebagai fasilitator. Prmbelajaran induktif yang digunakan ada dua modle, yaitu model taba dan SharanSharma. Kedua model pembelajaran induktif ini sama-sama berlangsung dari khusus ke umum, tahapan-tahapan yang ada dalam kedua pembelajaran induktif ini dapat melatih siswa untuk berpikir secara sistematis serta dapat mengembangkan kemampuan berpikir melalui observasi, menganalisis dan menggeneralisasi.

Berdasarkan uraian tersebut, maka rumusan masalah dalam penelitian ini adalah Bagaimana proses pembelajaran matematika menggunakan model pembelajaran induktif Taba dan induktif Sharan-Sharma?Apakah terdapat perbedaan kemampuan penalaran matematis siswa yang pembelajarannya menggunakan model pembelajaran induktif Taba, pembelajaran induktif SharanSharma dengan yang memperoleh pembelajaran konvensional?Bagaimana self-regulated learning siswa yang menggunakan model pembelajaran induktif Taba dan pembelajaran induktif SharanSharma?

\section{Metodologi Penelitian}

Penelitian ini menggunakan metode eksperimen dengan desain Quasi Jurnal Analisa Vol. 3 No. 1 Juni 2017: 56-69 
experimental yaitu Nonrandomized Control

Group Pretest-Posttest Design. Penelitian eksperimen ini dilakukan di kelas VII sekolah menengah pertama dengan sampel tiga kelas yaitu kelas VII D, VII E, dan VII F. Pengambilan sampel kelas secara NonProbability Sampling yaitu dengan Purposive Sampling. Purposive Sampling adalah teknik penentuan sampel dengan pertimbangan tertentu (Sugiyono, 2008:
68). Dengan pertimbangan sampel memiliki kemampuan matematika yang homogen antar kelas.

Untuk memperoleh data dari penelitian ini, maka diperlukan sumber data (instrumen). Instrumen yang digunakan dalam penelitian ini adalah tes kemampuan penalaran matematis, lembar observasi dan skala sikap self-regulated learning untuk siswa.

Tabel 1. Teknik Pengumpulan Data

\begin{tabular}{cllll}
\hline No. & $\begin{array}{c}\text { Sumber } \\
\text { Data }\end{array}$ & \multicolumn{1}{c}{ Aspek } & \multicolumn{1}{c}{$\begin{array}{c}\text { Instrumen } \\
\text { Penelitian }\end{array}$} & $\begin{array}{c}\text { Teknik } \\
\text { Pengumpulan } \\
\text { Data }\end{array}$ \\
\hline 1. & $\begin{array}{l}\text { Siswa dan } \\
\text { Guru }\end{array}$ & $\begin{array}{l}\text { Aktivitas siswa dan guru dalam } \\
\text { kegiatan pembelajaran } \\
\text { matematika }\end{array}$ & Lembar observasi & Observasi \\
\hline 3. & Siswa & $\begin{array}{l}\text { Kemampuan memecahkan } \\
\text { masalah penalaran matematis } \\
\text { siswa }\end{array}$ & $\begin{array}{l}\text { Tes (Pretesdan } \\
\text { Postes) }\end{array}$ & $\begin{array}{l}\text { Tes kemampuan } \\
\text { penalaran } \\
\text { matematis siswa }\end{array}$ \\
\hline 4. Siswa & $\begin{array}{l}\text { self-regulated learning dengan } \\
\text { model pembelajaran induktif. }\end{array}$ & $\begin{array}{l}\text { Lembar skala sikap } \\
\text { model Likert }\end{array}$ & Skalas ikap \\
\hline
\end{tabular}

Untuk mengetahui perbedaan kemampuan penalaran matematis siswa antara yang menggunakan model pembelajaran induktif Taba, pembelajaran induktif SharanSharma dan yang menggunakan

\section{Hasil dan Pembahasan}

Aktivitas guru dan siswa selama penelitian dapat dilihat pada gambar 1. pembelajaran konvensional digunakan uji ANOVA (Analisis of Variance) satu jalur dan data penelitian yang diambil adalah tes awal (pretest) dan tes akhir (posttest). 


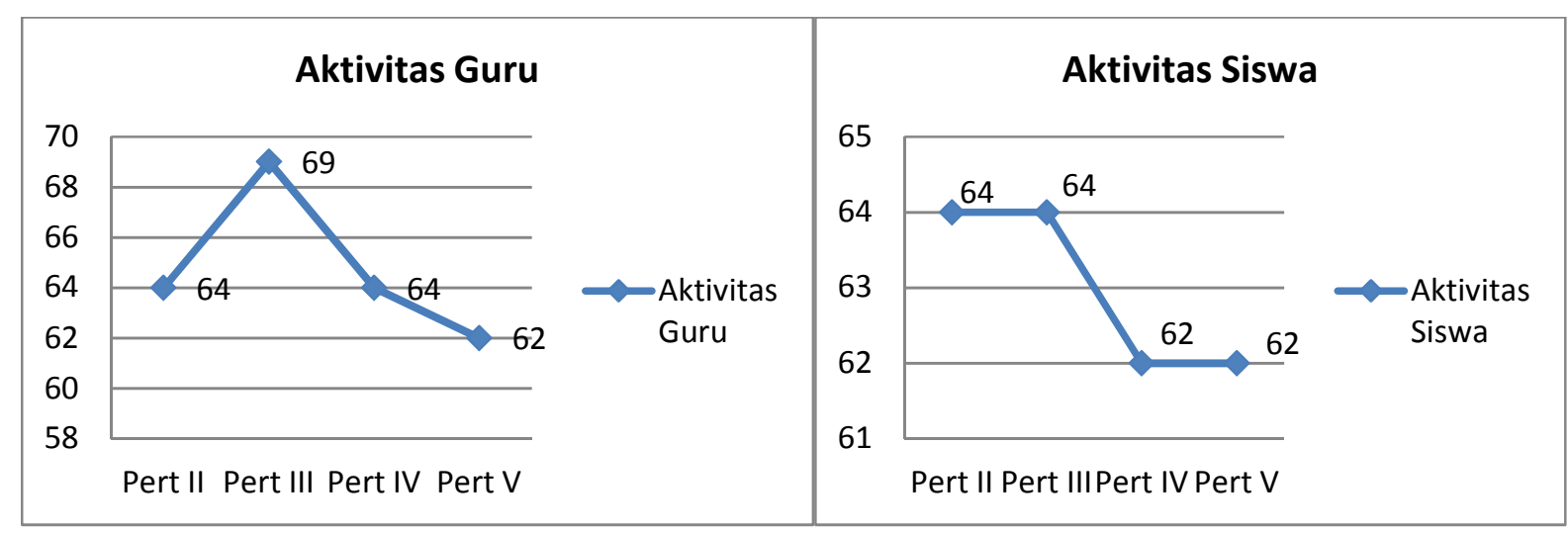

Gambar 1. Aktivitas Guru dan Siswa

Berdasarkan Gambar 1, dapat disimpulkan bahwa terdapat peningkatan pada aktivitas guru antara pertemuan ke dua dengan pertemuan ke tiga, sedangkan dari pertemuan ke tiga sampai pertemuan ke lima terjadi penurunan. Sementara untuk

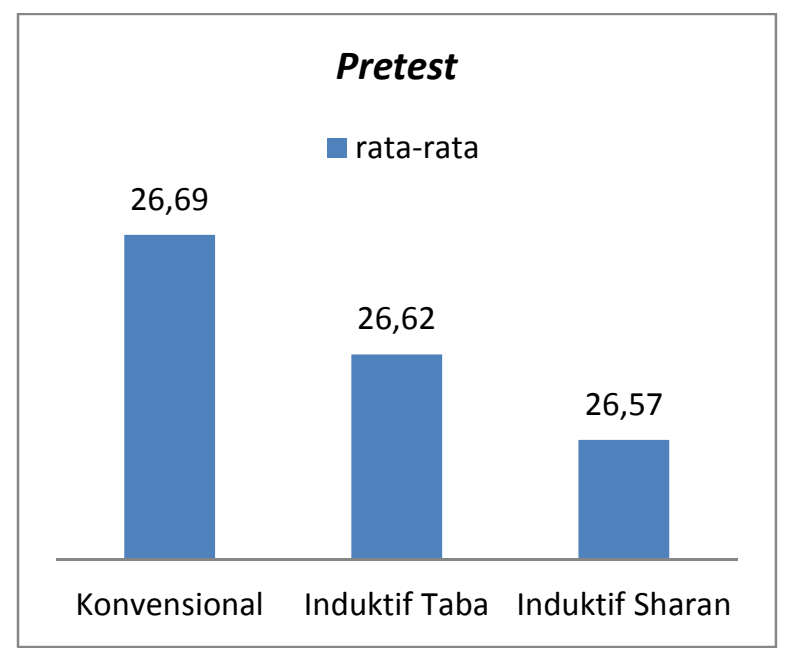

Gambar 2. Rata-rata Pretest

Dari gambar 2 terlihat bahwa rata-rata nilai pretest tertinggi adalah kelas konvensional, sedangkan yang terrendah adalah kelas induktif Sharan-Sharma. Hal ini kebalikan dengan hasil postest, posttest tertinggi dimiliki kelas induktif Sharan-Sharmadan aktivitas siswa terjadi penurunan dimulai dari pertemuan ke tiga sampai ke pertemuan ke lima, sedangkan pertemuan ke dua ke pertemuan ke tiga tetap. Sedangkan ratarata nilai pretestdan postestdari setiap kelas dapat dilihat dari Gambar 2 dan 3.

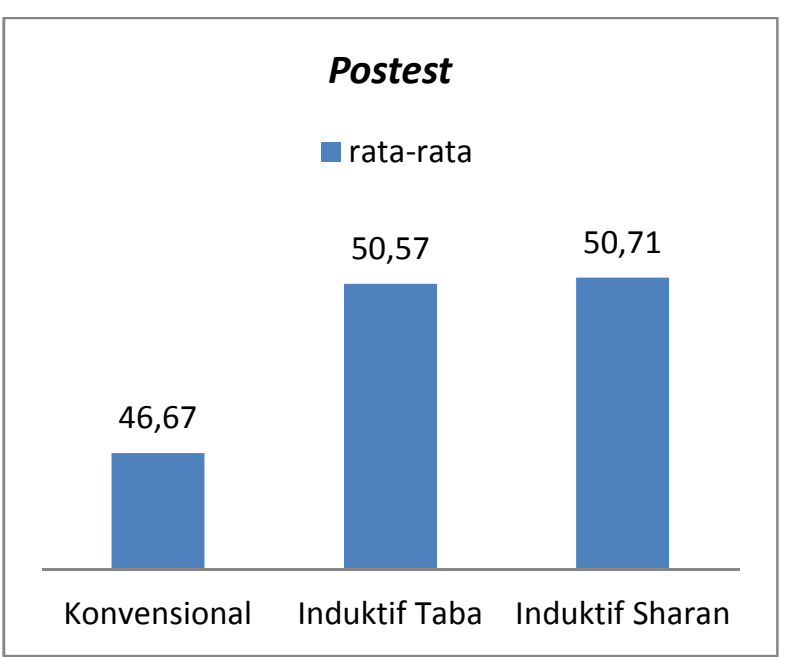

Gambar 3. Rata-rata Posttest

rata-rata posttest terendah dimiliki kelas konvensional dengan nilai posttest 46.67 . Sedangkan untuk kelas induktif Taba berada dibawah kelas Induktif SharanSharma dengan nilai posttest. 50.57 . 
Tabel 2. Uji Kruskal-Wallis Data Pretest

\begin{tabular}{cr} 
& \multicolumn{2}{c}{ Skor Siswa } \\
\hline Chi-Square & 6.295 \\
\hline df & 2 \\
\hline Asymp. Sig. & .043 \\
\hline
\end{tabular}

a. Kruskal Wallis Test

b. Grouping Variable: kelas

Pada Tabel 2, nilai Asymp. Sig $0.043<\quad$ Sharan-Sharma dan model pembelajaran 0.05 maka $\mathrm{H}_{0}$ ditolak, artinya terdapat konvensional.Selanjutnya akan dibahas perbedaan kemampuan penalaran pada analisis $L S D$ dalam Post Hoc test matematis siswa antara siswa yang untuk mengetahui pembelajaran mana saja menggunakan metode pembelajaran yang berbeda, yang dapat dilihat pada Tabel induktif Taba, pembelajaran induktif 3 sebagai berikut:

Tabel 3. Uji Post Hoc Data Posttest

\begin{tabular}{|c|c|c|c|c|c|c|}
\hline \multirow[b]{2}{*}{ (I) Kelas } & \multirow[b]{2}{*}{ (J) Kelas } & \multirow{2}{*}{$\begin{array}{l}\text { Mean } \\
\text { Difference } \\
(\mathrm{I}-\mathrm{J})\end{array}$} & \multirow[b]{2}{*}{$\begin{array}{l}\text { Std. } \\
\text { Error }\end{array}$} & \multirow[b]{2}{*}{ Sig. } & \multicolumn{2}{|c|}{$95 \%$ Confidence Interval } \\
\hline & & & & & Lower Bound & Upper Bound \\
\hline \multirow[t]{2}{*}{ Induktif Taba } & Induktif Sharan & .001 & .558 & .998 & -1.10 & 1.11 \\
\hline & Konvensional & $1.401^{*}$ & .568 & .015 & .27 & 2.53 \\
\hline \multirow[t]{2}{*}{ Induktif Sharan } & Induktif Taba & -.001 & .558 & .998 & -1.11 & 1.10 \\
\hline & Konvensional & $1.399^{*}$ & .551 & .012 & .31 & 2.49 \\
\hline \multirow[t]{2}{*}{ Konvensional } & Induktif Taba & $-1.401^{*}$ & .568 & .015 & -2.53 & -.27 \\
\hline & Induktif Sharan & $-1.399^{*}$ & .551 & .012 & -2.49 & -.31 \\
\hline
\end{tabular}

*. The mean difference is significant at the 0.05 level.

Dari Tabel 3, didapatkan nilai Sig. yaitu 0,998 $>0,05$ maka $H_{0}$ diterima sehingga dapat disimpulkan bahwa tidak terdapat perbedaan kemampuan penalaran matematis antara siswa yang memperoleh pembelajaran matematika menggunakan model pembelajaran induktif Taba dengan pembelajaran induktif Sharan-Sharma.

Dari Tabel 3 juga didapatkan nilai Sig. yaitu 0,012 $>0,05$ maka $H_{0}$ diterima sehingga dapat disimpulkan bahwa terdapat perbedaan pencapaian kemampuan penalaran matematis antara siswa yang memperoleh pembelajaran matematika menggunakan model pembelajaran induktif Taba dengan pembelajaran konvensional.Dan didapatkan nilai Sig. yaitu $0,015<0,05$ maka $H_{0}$ diterima sehingga dapat disimpulkan bahwa terdapat perbedaan kemampuan penalaran matematis antara siswa yang memperoleh pembelajaran matematika menggunakan model pembelajaran induktif Taba dengan 
pembelajaran konvensional. Sehingga pembelajaran tersebut tersaji pada Gambar perbedaan kemampuan penalaran 4.

matematis siswa diantara ketiga model

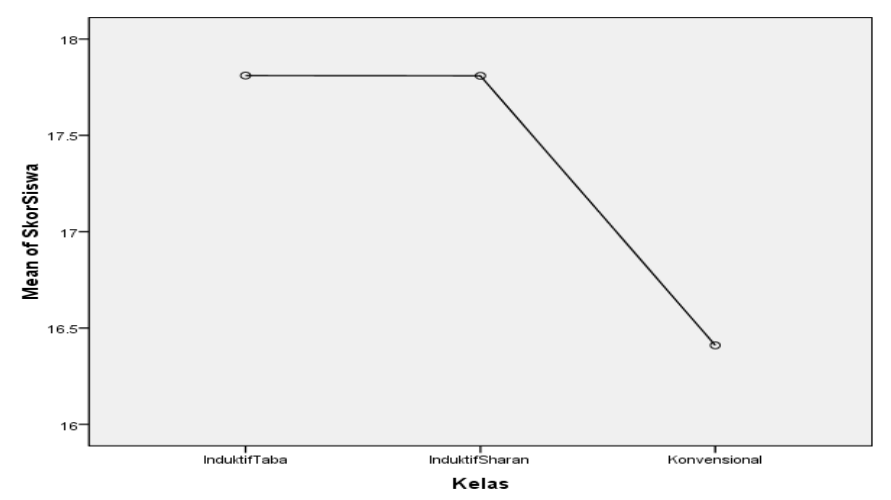

Gambar 4. Mean of Skor Posttest

Dari Gambar 4, terlihat kemampuan yaitu dengan rata-rata 50.57 dan rata-rata penalaran matematis dari model posttest terendah dimiliki kelas pembelajaran induktif Sharan-Sharma konvensional dengan nilai posttest 46.67. menduduki rata-rata nilai posttest tertinggi Berikut merupakan penjabaran untuk setiap yaitu dengan rata-rata 50.71, disusul dengan soal dan indikator penalaran matematis Mean model pembelajaran induktif Taba pada pretes maupun postes.

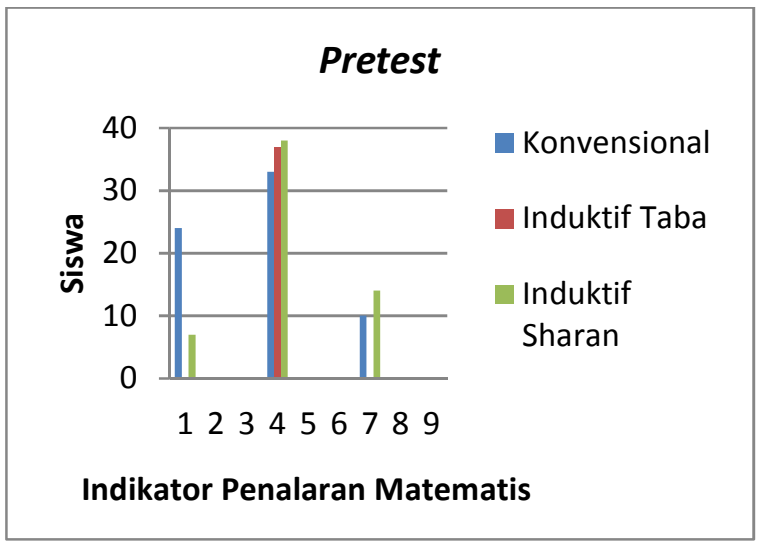

Gambar 5. Indikator Penalaran Matematis Pretest

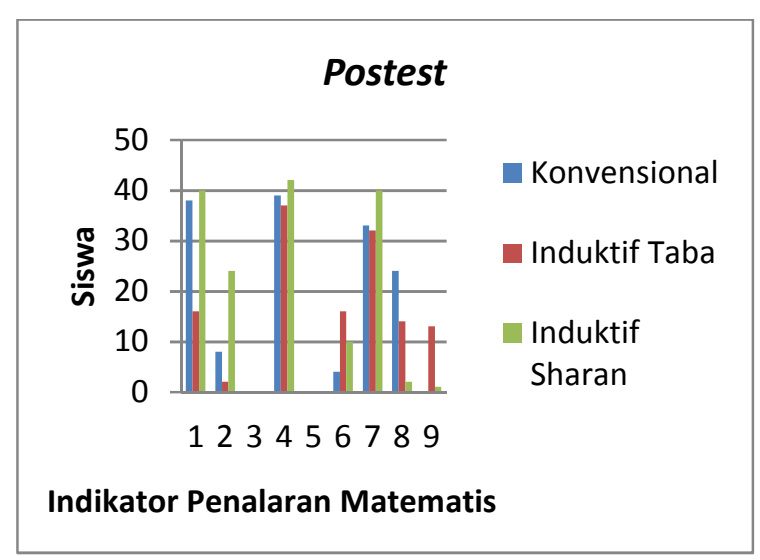

Gambar 6. Indikator Penalaran Matematis Post test

\section{Keterangan:}

\section{No Indikator}

1 Mengunakan pola dan hubungan untuk menganalisis situasi matematik

2 Menyusun konjektur

3 Memperkirakan jawaban

$4 \quad$ Melakukan pembuktian langsung

5 Membuat argumen yang valid

6 Merumuskan lawan contoh

7 Memberikan penjelasan dengan menggunakan model, fakta dan hubungan

8 Menarik kesimpulan logis

9 Memeriksa validitas argumen 
Untuk hasil skor skala self-regulated learningsiswa kelas VII E terhadap pembelajaran induktif Taba terdapat pada Tabel 4 berikut ini:

Tabel 4. Distribusi Skor Self-Regulated Learning Siswa Kelas VII-E

Terhadap Pembelajaran Induktif Taba

\begin{tabular}{|c|c|c|c|c|c|c|c|c|c|c|c|}
\hline \multirow[b]{2}{*}{ Indikator } & \multirow[b]{2}{*}{ Sub Indikator } & \multirow{2}{*}{\multicolumn{2}{|c|}{ No Soal }} & \multicolumn{5}{|c|}{ Jawaban } & \multicolumn{2}{|c|}{ Skor Siswa } & \multirow{2}{*}{$\begin{array}{c}\text { Skor } \\
\text { Siswa } \\
\text { Netral }\end{array}$} \\
\hline & & & & $\begin{array}{l}\text { S } \\
\text { S }\end{array}$ & $\mathrm{Sr}$ & $\mathbf{K}$ & $\mathbf{J r}$ & $\mathbf{J S}$ & Item & \multirow[t]{3}{*}{ Kelas } & \\
\hline \multirow{2}{*}{$\begin{array}{c}\text { Mendiagnosa } \\
\text { kebutuhan } \\
\text { belajar }\end{array}$} & \multirow{2}{*}{$\begin{array}{c}\text { Belajar dengan } \\
\text { menemukan } \\
\text { konsep sendiri }\end{array}$} & \multirow[b]{2}{*}{6} & Skor & 5 & 4 & 3 & 2 & 1 & \multirow[b]{2}{*}{3,4} & & \multirow{8}{*}{3} \\
\hline & & & + & 0 & 3 & 22 & 11 & 1 & & & \\
\hline \multirow[b]{2}{*}{$\begin{array}{c}\text { Memilih dan } \\
\text { menetapkan } \\
\text { strategi } \\
\text { belajar }\end{array}$} & \multirow[b]{2}{*}{$\begin{array}{c}\text { Belajar dengan } \\
\text { melakukan } \\
\text { pengamatan, } \\
\text { mengobservasi } \\
\text { dan generalisasi }\end{array}$} & \multirow[b]{2}{*}{21} & Skor & 1 & 2 & 3 & 4 & 5 & \multirow[b]{2}{*}{2,5} & \multirow{6}{*}{2,9} & \\
\hline & & & - & 6 & 11 & 16 & 5 & 0 & & & \\
\hline \multirow{4}{*}{$\begin{array}{c}\text { Mengevaluasi } \\
\text { proses dan } \\
\text { hasil belajar }\end{array}$} & \multirow{2}{*}{$\begin{array}{c}\text { Mengerjakan } \\
\text { soal dengan tipe } \\
\text { berbeda setelah } \\
\text { mempelajari } \\
\text { materi }\end{array}$} & \multirow[b]{2}{*}{25} & Skor & 5 & 4 & 3 & 2 & 1 & \multirow[b]{2}{*}{2,8} & & \\
\hline & & & + & 1 & 5 & 18 & 10 & 3 & & & \\
\hline & \multirow{2}{*}{$\begin{array}{c}\text { Kesukaan } \\
\text { terhadap model } \\
\text { pembelajaran } \\
\text { induktif }\end{array}$} & \multirow[b]{2}{*}{26} & Skor & 1 & 2 & 3 & 4 & 5 & \multirow[b]{2}{*}{2,9} & & \\
\hline & & & 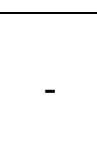 & 1 & 6 & 25 & 4 & 1 & & & \\
\hline
\end{tabular}

Berdasarkan Tabel 4, dapat dilihat klasifikasi skor siswa bernilai 2,9 sedangkan klasifikasi skor netral 3 maka $2,9<3$ sehingga dapat disimpulkan bahwa self-regulated learning siswa terhadap pembelajaran induktif Taba menunjukkan hasil yang negatif.

Setelah menganalisis self-regulated learning siswa terhadap pembelajaran induktif, selanjutnya akan dianalisis selfregulated learning siswa untuk setiap indikator. Berdasarkan penelitian, dapat diketahui bahwa klasifikasi skor selfregulated learning siswa bernilai 2,85 sedangkan klasifikasi skor sikap netral 3 maka 2,85 $<3$ dapat disimpulkan bahwa self-regulated learning siswa terhadap pembelajaran matematika dengan model pembelajatan induktif Taba menunjukkan hasil negatif.

Untuk hasil distribusi skor sikap selfregulated learning siswa secara keseluruhan untuk kelas VII-F terdapat pada Tabel 5. 
Tabel 5. Distribusi Skor Self-Regulated Learning Siswa Kelas VII-F

\begin{tabular}{|c|c|c|c|c|c|c|c|c|c|c|c|}
\hline \multirow[b]{2}{*}{ Indikator } & \multirow{2}{*}{\multicolumn{2}{|c|}{ No Soal }} & \multicolumn{5}{|c|}{ Jawaban } & \multicolumn{2}{|c|}{ Skor Siswa } & \multirow{2}{*}{$\begin{array}{c}\text { Skor } \\
\text { Siswa } \\
\text { Netral }\end{array}$} & \multirow[b]{2}{*}{ Skor SLR } \\
\hline & & & SS & $\mathrm{Sr}$ & $\mathbf{K}$ & $\mathbf{J r}$ & $\mathbf{J S}$ & Item & Kelas & & \\
\hline \multirow{6}{*}{ Inisiatif belajar } & 1 & Skor & 1 & 2 & 3 & 4 & 5 & 2,88 & \multirow{6}{*}{2,61} & \multirow{6}{*}{3} & \\
\hline & & - & 0 & 9 & 31 & 0 & 2 & 1 & & & \\
\hline & 2 & Skor & 5 & 4 & 3 & 2 & 1 & 2,1 & & & \\
\hline & & + & 0 & 1 & 15 & 13 & 13 & & & & \\
\hline & 3 & Skor & 5 & 4 & 3 & 2 & 1 & 2,86 & & & \\
\hline & & + & 1 & 5 & 26 & 7 & 3 & & & & \\
\hline \multirow{8}{*}{$\begin{array}{c}\text { Mendiagnosa } \\
\text { kebutuhan belajar }\end{array}$} & 5 & Skor & 1 & 2 & 3 & 4 & 5 & 3,3 & \multirow{8}{*}{3,075} & \multirow{8}{*}{3} & \\
\hline & & - & 1 & 4 & 22 & 11 & 4 & & & & \\
\hline & 6 & Skor & 5 & 4 & 3 & 2 & 1 & 3,3 & & & \\
\hline & & + & 2 & 12 & 16 & 8 & 4 & & & & \\
\hline & 7 & Skor & 1 & 2 & 3 & 4 & 5 & 3 & & & \\
\hline & & - & 1 & 12 & 26 & 3 & 0 & & & & \\
\hline & 4 & Skor & 1 & 2 & 3 & 4 & 5 & 2,7 & & & \\
\hline & & - & 0 & 7 & 19 & 13 & 3 & & & & \\
\hline \multirow{6}{*}{$\begin{array}{c}\text { Menetapkan tujuan } \\
\text { belajar }\end{array}$} & 8 & Skor & 1 & 2 & 3 & 4 & 5 & 2,9 & \multirow{6}{*}{2,5} & \multirow{6}{*}{3} & \\
\hline & & - & 2 & 9 & 22 & 8 & 1 & & & & \\
\hline & 9 & Skor & 5 & 4 & 3 & 2 & 1 & 1,8 & & & \\
\hline & & + & 0 & 0 & 12 & 9 & 21 & & & & \\
\hline & 10 & Skor & 1 & 2 & 3 & 4 & 5 & 2,8 & & & \\
\hline & & - & 7 & 9 & 22 & 13 & 1 & & & & \\
\hline \multirow{6}{*}{$\begin{array}{c}\text { Memonitor, } \\
\text { mengatur dan } \\
\text { mengontrol belajar }\end{array}$} & 13 & Skor & 1 & 2 & 3 & 4 & 5 & 3,2 & \multirow{6}{*}{2,81} & \multirow{6}{*}{3} & 2,9 \\
\hline & & - & 3 & 8 & 20 & 9 & 1 & & & & \\
\hline & 11 & Skor & 5 & 4 & 3 & 2 & 1 & 2,31 & & & \\
\hline & & + & 4 & 9 & 23 & 5 & 1 & & & & \\
\hline & 12 & Skor & 5 & 4 & 3 & 2 & 1 & 2,93 & & & \\
\hline & & + & 0 & 4 & 17 & 9 & 12 & & & & \\
\hline \multirow{8}{*}{$\begin{array}{l}\text { Memandang } \\
\text { kesulitan sebagai } \\
\text { tantangan }\end{array}$} & 16 & Skor & 5 & 4 & 3 & 2 & 1 & 2,86 & \multirow{8}{*}{3,215} & \multirow{8}{*}{3} & \\
\hline & & + & 2 & 12 & 23 & 5 & 1 & & & & \\
\hline & 17 & Skor & 5 & 4 & 3 & 2 & 1 & 3,48 & & & \\
\hline & & + & 1 & 20 & 13 & 7 & 1 & & & & \\
\hline & 14 & Skor & 1 & 2 & 3 & 4 & 5 & 3,21 & & & \\
\hline & & $=$ & 2 & 10 & 23 & 6 & 1 & & & & \\
\hline & 15 & Skor & 1 & 2 & 3 & 4 & 5 & 3,31 & & & \\
\hline & & $\ldots$ & 0 & 5 & 21 & 7 & 9 & & & & \\
\hline \multirow{7}{*}{$\begin{array}{c}\text { Memanfaatkan dan } \\
\text { mencari sumber } \\
\text { belajar yang } \\
\text { relevan }\end{array}$} & 20 & Skor & 1 & 2 & 3 & 4 & 5 & 2,93 & & & \\
\hline & & - & 3 & 10 & 21 & 6 & 2 & & & & \\
\hline & 18 & Skor & 5 & 4 & 3 & 2 & 1 & 3,2 & 301 & 3 & \\
\hline & & + & 0 & 8 & 24 & 9 & 1 & & 3,01 & 3 & \\
\hline & 19 & Skor & 5 & 4 & 3 & 2 & 1 & 2,9 & & & \\
\hline & & + & 3 & 11 & 23 & 5 & 1 & & & & \\
\hline & 21 & Skor & 1 & 2 & 3 & 4 & 5 & 2,9 & 2,975 & 3 & \\
\hline
\end{tabular}




\begin{tabular}{|c|c|c|c|c|c|c|c|c|c|c|c|}
\hline \multirow{9}{*}{$\begin{array}{l}\text { Indikator } \\
\text { Memilih dan } \\
\text { menetapkan strategi } \\
\text { belajar }\end{array}$} & \multirow{2}{*}{\multicolumn{2}{|c|}{ No Soal }} & \multicolumn{5}{|c|}{ Jawaban } & \multicolumn{2}{|c|}{ Skor Siswa } & \multirow{9}{*}{$\begin{array}{c}\text { Skor } \\
\text { Siswa } \\
\text { Netral }\end{array}$} & \multirow{9}{*}{ Skor SLR } \\
\hline & & & SS & Sr & $\mathbf{K}$ & $\mathbf{I r}$ & IS & Item & Kolag & & \\
\hline & & - & 1 & 6 & 30 & 5 & 0 & & & & \\
\hline & \multirow[t]{2}{*}{22} & Skor & 1 & 2 & 3 & 4 & 5 & \multirow[t]{2}{*}{3,1} & & & \\
\hline & & - & 4 & 4 & 22 & 9 & 3 & & & & \\
\hline & \multirow[t]{2}{*}{23} & Skor & 5 & 4 & 3 & 2 & 1 & \multirow[t]{2}{*}{2,5} & & & \\
\hline & & + & 1 & 4 & 19 & 9 & 9 & & & & \\
\hline & \multirow[t]{2}{*}{24} & Skor & 5 & 4 & 3 & 2 & 1 & \multirow[t]{2}{*}{3,4} & & & \\
\hline & & + & 4 & 14 & 19 & 3 & 2 & & & & \\
\hline \multirow{6}{*}{$\begin{array}{l}\text { Mengevaluasi } \\
\text { proses dan hasil } \\
\text { belajar }\end{array}$} & \multirow[t]{2}{*}{25} & Skor & 5 & 4 & 3 & 2 & 1 & \multirow[t]{2}{*}{2,8} & \multirow{6}{*}{3} & \multirow{6}{*}{3} & \\
\hline & & + & 1 & 6 & 23 & 8 & 4 & & & & \\
\hline & 26 & Skor & 1 & 2 & 3 & 4 & 5 & 3,1 & & & \\
\hline & & - & 1 & 6 & 24 & 10 & 1 & & & & \\
\hline & \multirow[t]{2}{*}{27} & Skor & 1 & 2 & 3 & 4 & 5 & \multirow[t]{2}{*}{3,1} & & & \\
\hline & & - & 1 & 8 & 22 & 8 & 3 & & & & \\
\hline \multirow{6}{*}{ Konsep diri } & \multirow[t]{2}{*}{28} & Skor & 5 & 4 & 3 & 2 & 1 & \multirow[t]{2}{*}{3,2} & \multirow{6}{*}{2,94} & \multirow{6}{*}{3} & \\
\hline & & + & 2 & 9 & 27 & 2 & 2 & & & & \\
\hline & \multirow[t]{2}{*}{29} & Skor & 1 & 2 & 3 & 4 & 5 & \multirow[t]{2}{*}{2,93} & & & \\
\hline & & - & 0 & 11 & 24 & 6 & 1 & & & & \\
\hline & \multirow[t]{2}{*}{30} & Skor & 1 & 2 & 3 & 4 & 5 & \multirow[t]{2}{*}{2,7} & & & \\
\hline & & - & 0 & 20 & 17 & 4 & 1 & & & & \\
\hline
\end{tabular}

Berdasarkan Tabel 5, dapat dilihat klasifikasi skor self-regulated learning siswa bernilai 2,9 sedangkan klasifikasi skor netral 3 maka $2,9<3$ dapat disimpulkan bahwa self-regulated learning siswa model pembelajaran induktif SharanSharma bernilainegatif.
Untuk selanjutnya akan dianalisis sikap self-regulated learning siswa terhadap pembelajaran induktif Sharan-Sharma. Untuk hasil skor skala self-regulated learning siswa kelas VII E terhadap pembelajaran induktif Sharan-Sharma terdapat pada Tabel 6 .

Tabel 6. Distribusi Skor Self-Regulated Learning siswa kelas VII-F Terhadap Pembelajaran Induktif Sharan-Sharma

\begin{tabular}{|c|c|c|c|c|c|c|c|c|c|c|c|}
\hline \multirow[b]{2}{*}{ Indikator } & \multirow[b]{2}{*}{ Sub Indikator } & \multirow{2}{*}{\multicolumn{2}{|c|}{ No Soal }} & \multicolumn{5}{|c|}{ Jawaban } & \multicolumn{2}{|c|}{ Skor Siswa } & \multirow{2}{*}{$\begin{array}{l}\text { Skor } \\
\text { Siswa } \\
\text { Netral }\end{array}$} \\
\hline & & & & SS & $\mathrm{Sr}$ & $\mathbf{K}$ & $\mathbf{J r}$ & JS & Item & Kelas & \\
\hline \multirow{2}{*}{$\begin{array}{c}\text { Mendiagnosa } \\
\text { kebutuhan } \\
\text { belajar }\end{array}$} & Belajar dengan & 6 & Skor & 5 & 4 & 3 & 2 & 1 & 3,3 & \multirow{4}{*}{3,025} & \multirow{4}{*}{3} \\
\hline & $\begin{array}{c}\text { menemukan konsep } \\
\text { sendiri }\end{array}$ & & + & 2 & 11 & 16 & 9 & 4 & & & \\
\hline \multirow{2}{*}{$\begin{array}{l}\text { Memilih dan } \\
\text { menetapkan } \\
\text { strategi belajar }\end{array}$} & \multirow{2}{*}{$\begin{array}{l}\text { Belajar dengan } \\
\text { melakukan } \\
\text { pengamatan, }\end{array}$} & \multirow[t]{2}{*}{21} & Skor & 1 & 2 & 3 & 4 & 5 & \multirow[t]{2}{*}{2,9} & & \\
\hline & & & - & 1 & 6 & 30 & 5 & 0 & & & \\
\hline
\end{tabular}




\begin{tabular}{|c|c|c|c|c|c|c|c|c|c|c|c|}
\hline \multirow{3}{*}{ Indikator } & \multirow{3}{*}{$\begin{array}{l}\text { Sub Indikator } \\
\text { mengobservasi dan } \\
\text { generalisasi }\end{array}$} & \multirow{2}{*}{\multicolumn{2}{|c|}{ No Soal }} & \multicolumn{5}{|c|}{ Jawaban } & \multicolumn{2}{|c|}{ Skor Siswa } & \multirow{7}{*}{$\begin{array}{c}\text { Skor } \\
\text { Siswa } \\
\text { Netral }\end{array}$} \\
\hline & & & & SS & $\mathrm{Sr}$ & $\mathbf{K}$ & $\mathbf{J r}$ & JS & Item & Kelas & \\
\hline & & & & & & & & & & & \\
\hline \multirow{4}{*}{$\begin{array}{l}\text { Mengevaluasi } \\
\text { proses dan } \\
\text { hasil belajar }\end{array}$} & \multirow{2}{*}{$\begin{array}{c}\text { Mengerjakan soal } \\
\text { dengan tipe berbeda } \\
\text { setelah mempelajari } \\
\text { materi }\end{array}$} & \multirow[t]{2}{*}{25} & Skor & 5 & 4 & 3 & 2 & 1 & \multirow[t]{2}{*}{2,8} & & \\
\hline & & & + & 1 & 6 & 23 & 8 & 4 & & & \\
\hline & \multirow{2}{*}{$\begin{array}{c}\text { Kesukaan terhadap } \\
\text { model } \\
\text { pembelajaran } \\
\text { induktif }\end{array}$} & \multirow[t]{2}{*}{26} & Skor & 1 & 2 & 3 & 4 & 5 & \multirow[t]{2}{*}{3,1} & & \\
\hline & & & - & 1 & 6 & 24 & 10 & 1 & & & \\
\hline
\end{tabular}

Dapat dilihat klasifikasi skor siswa bernilai 3,025 sedangkan klasifikasi skor netral 3 maka 3,025 > 3 dapat disimpulkan bahwa self-regulated learning siswa terhadap pembelajaran induktif Sharan-Sharma bernilaipositif.

Berdasarkan hasil temuan pada lembar observasi aktivitas guru dan siswa untuk model pembelajaran induktif Taba pada pertemuan keduaguru masih terlihat kaku melaksanakan proses pembelajaran hal ini disebabkan karena guru pertama kali mengajar di kelas penelitian dengan model pembelajaran ini sehingga siswa juga terlihat masih bingung. Hasil temuan pada lembar observasi aktivitas guru dan siswa untuk model pembelajaran induktif SharanSharma pada pertemuan kedua, guru masih belum bisa mengatur waktu dengan baik, aktivitas siswa pun juga belum terlihat berjalan dengan baik, seperti siswa yang masih kebingungan memahami materi tanpa diterangkan terlebih dahulu oleh guru, hal ini disebabkan karena siswa masih belum terbiasa dengan model tersebut. Pertemuan ketiga juga tidak jauh berbeda, hanya pada saat pemebentukan kelompok ada beberapa siswa yang ingin berpindah kelompok, dan berkunjung ke kelompok lain sehingga persentasi aktivitas siswa menurun.

Pada pertemuan keempat siswa terlihat lebih aktif dan serius dalam berdiskusi, tetapi tetap saja aktifitas berkunjung ke kelompok lain masih dilaksanakan dan siswa masih belum memberikan tanggapan ketika siswa lain presentasi, mereka mengeluh belajar matematika dengan menemukan konsep sendiri sangat membingungkan.

Pertemuan keempat terlihat aktivitas siswa dan guru mengalami penurunan, waktu habis ketika proses pengamatan, pada tahap ini siswa mengobservasi mengenai luas Jurnal Analisa Vol. 3 No. 1 Juni 2017: 56-69 
segiempat, tahap generalisasi, uji dan verifikasi tidak terlaksana sehingga tidak ada yang presentasi, tidak ada yang memberikan tanggapan. Secara keseluruhan proses pembelajaran induktif SharanSharma cukup baik meskipun ada beberapa tahapan yang tidak terlaksana pada pertemuan terakhir.

Adanya penurunan aktifitas siswa maupun guru karena ada beberapa tahapan yang tidak terlaksana akibat waktu pembelajaran habis pada saat siswa mengobservasi dan bereksperimen.

Dari hasil penelitian didapatkan, tidak terdapat perbedaan pencapaian kemampuan penalaran matematis siswa antara yang menggunakan model pembelajaran induktif Taba dengan model pembelajaran induktif Sharan-Sharma. Terdapat perbedaan pencapaian penalaran matematis matematika antara siswa yang memperoleh pembelajaran matematika menggunkan model pembelajaran induktif Taba dengan pembelajaran konvensional.Terdapat perbedaan pencapaian kemampuan penalaran matematis antara siswa yang memperoleh pembelajaran matematika menggunkan model pembelajaran induktif Sharan-Sharma dengan pembelajaran konvensional.
Sharan dan Sharma (Mayadiana, 2011: 85) yang menegaskan bahwa pembelajaran induktif didasarkan pada proses induksi. Permana (Sumarmo, 2013) juga menyatakan bahwa induksi merupakan penarikan kesimpulan berdasarkan sejumlah kasus atau contoh terbatas. Induksi yang menghasilkan kesimpulan umum dinamakan generalisasi.

Dari hasil penelitian didapatkan, untuk selfregulated learning siswa kelas VII-E yang menggunakan model pembelajaran induktif Taba dan kelas VII-F yang menggunakan model pembelajaran induktif SharanSharma keduanya bernilai negatif karena skor self-regulated learning lebih kecil dari skor netral. Berdasarkan hal tersebut, dapat diketahui bahwa siswa kurang antusias untuk menemukan konsep secara mandiri dalam pembelajaran matematika. Ada beberapa hal yang dapat mempengaruhi rendahnya self-regulated learning, sesuai dengan pendapat Woolfolk (Sumarni, 2014: 27) menyatakan bahwa faktor-faktor yang mempengaruhi self-regulated learning meliputi: pengetahuan (knowledge), motivasi (motivation) dan disiplin pribadi (self-discipline). Berdasarkan pernyataan tersebut siswa yang mempunyai selfregulated learningakan memiliki respon positif terhadap pembelajaran apapun yang 
diterapkan sehingga dapat mengikuti pembelajaran dengan baik.

\section{Simpulan dan Saran}

Berdasarkan hasil penelitian dan pembahasan tentang kemampuan penalaran matematis antara siswa yang menggunakan model pembelajaran induktif Taba, pembelajaran induktif Sharan-Sharma dan metode konvensional, diperoleh kesimpulan sebagai berikut:1) Gambaran proses pembelajaran matematika dengan menggunakan model pembelajaran induktif Taba dan pembelajaran induktif SharanSharma secara keseluruhan terlaksana

\section{Daftar Pustaka}

Ariany, R.L. 2014. Penerapan Starategi Pembelajaran Multiple Inteligence Untuk Meningkatkan Kemampuan Penalaran dan Disposisi Matematis Siswa SMP. Tesis SPs UPI. Bandung: Tidak diterbitkan.

Armiati. 2011. Peningkatan Kemampuan Penalaran Matematis, Komunikasi Matematis, dan Kecerdasan Emosional Mahasiswa Melalui Pembelajaran Berbasis Masalah. Disertasi pada PPs UPI. Bandung: Tidak diterbitkan.

Dahiana, W.O. 2010. Peningkatan Kemampuan Pemahaman dan Generalisasi Matematis Siswa MTS melalui Pendekatan Induktif-Deduktif Berbasis Konstruktivisme. Tesis SPs UPI. Bandung: Tidak diterbitkan.

Kariadinata, R. 2011. Statistika Penelitian Pendidikan dilengkapi Pengolahan Data dengan program SPSS. Bandung: Insan mandiri.

Mayadiana, D. 2011. Mengembangkan Kemampuan Penalaran dan Pemecahan Masalah Mahasiswa dengan cukup baik, 2) Terdapat perbedaan kemampuan penalaran matematis antara siswa yang memperoleh model pembelajaran induktif Taba, pembelajaran induktif Sharan-Sharma dengan pembelajaran konvensional. 3) Pembelajaran matematika dengan menggunakan pembelajaran induktif dapat meningkatkan pencapaian kemampuan penalaran matematis siswa. 4) Selfregulated learning siswa yang model pembelajaran induktif Taba dan pembelajaran induktif Sharan-Sharma menunjukkan hasil negatif.

Calon Guru SD Melalui Pembelajaran dengan Pendekatan Induktif. Disertasi pada PPs UPI. Bandung: Tidak diterbitkan.

NCTM. 1989. Curriculum and Evaluation Standards for School Mathematics. Reston, VA: Author.

Pintrich, P.R. dan De Groot, E. 1990. Motivational and Self-Regulated Learning Component of Classroom Academic

Performance.JournalofEducational Psychology 19,Vol. 82, No.1,33-40 http://rhartshorne.com/fall2012/eme6507-rh/cdisturco/eme6507eportfolio/documents/pintrich\%20and \%20degroodt\%201990.pdf

Rahmah, M.A. 2012. Pendekatan DeduktifInduktif untuk Meningkatkan Kemampuan Pemahaman dan Pemecahan Masalah Matematis pada Siswa SMP. Tesis SPs UPI. Bandung: Tidak diterbitkan

Risnawati. 2012. Pengaruh Pembelajaran dengan Pendekatan Induktif- Deduktif Berbantuan Program Cabri Geometri Terhadap Peningkatan Kemampuan 
Representasi Matematis Siswa SMA. Tesis pada PPs UPI. Bandung: Tidak diterbitkan.

Rosadi,B.D. $2013 \quad$ Penerapan Pembelajaran Strategi Index Card Match Untuk Meningkatkan Kemampuan Penalaran Matematika Siswa Pada Pokok Bahasan Segiempat. Skripsi FMIPA UIN. Bandung: Tidak diterbitkan.

Ruseffendi, E.T. 2006. Pengantar Kepada Membantu Guru Mengembangkan Kompetensinya Dalam Pengajaran Matematika Untuk Meningkatkan CBSA. Bandung: Tarsito.

Sumarmo, U. 2013. Berfikir dan Disposisi Matematik Serta Pembelajarannya:
Apa, Mengapa dan Bagaimana Dikembangkan pada Peserta Didik. Bandung: FMIPA UPI. Tidak diterbitkan

Sumarni. 2014. Penerapan Learning Cycle $5 E$ untuk Meningkatkan Kemampuan Koneksi dan Komunikasi Matematis Serta Self-Regulated Learning Matematika Siswa. Tesis SPs UPI. Bandung: Tidak diterbitkan.

Wahyudin. 1999. Kemampuan Guru Matematika, Calon Guru Matematika dan Siswa dalam Mata Pelajaran Matematika. Disertasi pada PPs UPI. Bandung: Tidak diterbitkan. 